This PDF is a selection from an out-of-print volume from the National Bureau of Economic Research

Volume Title: The Frontiers of Economic Knowledge

Volume Author/Editor: Arthur F. Burns

Volume Publisher: Princeton University Press

Volume ISBN: 0-87014-056-6

Volume URL: http://www.nber.org/books/burn54-1

Publication Date: 1954

Chapter Title: Keynesian Economics Once Again

Chapter Author: Arthur F. Burns

Chapter URL: http://www.nber.org/chapters/c0392

Chapter pages in book: (p. 207 - 235) 


\section{Keynesian Economics Once Again}

Professor Hansen's paper in this number of the Review deals with important issues of economic theory. It expresses the judgment of a leading Keynesian thinker, who has had full opportunity to weigh and refine his reasons for repudiating my interpretation of Keynes. ${ }^{1}$ Every mature economist knows how barren controversy can be and, in fact, usually is. But Keynes' theory is now at the center of much of our economic thinking, and Hansen is its outstanding exponent. Under the circumstances, it may serve the interests of economic science to examine Hansen's strictures with some care. I am grateful to the Editors of the Review for according me the opportunity.

In the following pages I shall consider the major issues raised by Hansen. Section $I$ is devoted to the essentials of Keynes' theory of income and employment, Section II to its determinacy, Section III to the consumption function, and Section IV to the Keynesian apparatus as distinguished from the Keynesian theory. An appendix on Keynes' business cycle theory brings the paper to a close.

\section{Keynes' TheORY OF InCOME AND Employment}

In the essay on Economic Research and the Keynesian Thinking of Our Times, ${ }^{2}$ I boldly attempted to set forth the essence of Keynes' General Theory in a few paragraphs. To enable the reader to follow closely the questions raised by Hansen, I shall reproduce the main part of the original sketch before taking up the criticisms:

Reprinted by permission from The Review of Economic Statistics (published by Harvard University Press), November 1947, pp. 252-267.

1 In the November 1946 issue of this Review Alvin $H$. Hansen comments on the great difficulty that economists have experienced in grasping Keynes' General Theory. In this connection he makes the following pronouncement: "A recent example disclosing a number of elementary misconceptions is the pamphlet by Arthur F. Burns, on Economic Research and the Keynesian Thinking of Our Times (National Bureau of Economic Research, 1946). However, the pamphlet does strikingly reveal (perhaps inadvertently) how economic theory-whether Ricardian or Keynesian-serves the highly useful purpose of pointing up what factual data are relevant to a useful investigation" (p. 187). Since this statement was not accompanied by any evidence, I was of course interested and eager to know what my misconceptions may be. In the course of the ensuing correspondence, Hansen eventually set forth his views in some detail. I replied as fully. Hansen's paper in this Review presents the critical remarks that he developed in correspondence, with such elaborations and modifications as he has deemed necessary to present his case properly before the scientific public.

2 Hereafter referred to as Keynesian Thinking. [Reprinted on pages 3-25, above; page references that follow are to the present volume.] 
“... Keynes' theory of underemployment equilibrium . . . attempts to show that a free enterprise economy, unless stimulated by governmental policies, may sink into a condition of permanent mass unemployment. The crux of this theory is that the volume of investment and the 'propensity to consume' determine between them a unique level of income and employment. The theory can be put simply without misrepresenting its essence. Assume that business firms in the aggregate decide to add during a given period $\$ 2$ billion worth of goods to their stockpiles, using this convenient term to include new plant and equipment as well as inventories. This then is the planned investment. Assume, next, that business firms do not plan to retain any part of their income; ${ }^{3}$ so that if they pay out, say, $\$ 18$ billion to the public, they expect to recover $\$ 16$ billion through the sale of consumer goods, the difference being paid out on account of the expected addition to their stockpiles. Assume, finally, that the 'consumption function' has a certain definite shape; that if income payments are, say, $\$ 18$ billion, the public will spend $\$ 17$ billion on consumer goods and save $\$ 1$ billion, and that one-half of every additional billion dollars of income will be devoted to consumption and one-half to savings. Under these conditions, the national income per 'period' should settle at a level of $\$ 20$ billion.

"The reason is as follows. If income payments were $\$ 18$ billion, the public would spend $\$ 17$ billion on consumer goods. But the firms that made these payments expected to sell $\$ 16$ billion worth to the public and to add $\$ 2$ billion worth to their stockpiles; the actual expenditure of $\$ 17$ billion on consumer goods would therefore exceed sellers' expectations by $\$ 1$ billion, and stimulate expansion in the consumer goods trades. On the other hand, if income payments were $\$ 22$ billion, the public would spend $\$ 19$ billion on consumer goods; this would fall short of sellers' expectations by $\$ 1$ billion, and set off a contraction in the output of consumer goods. In general, if income payments fell below $\$ 20$ billion, the sales expectations of business firms would be exceeded; while if income payments rose above $\$ 20$ billion, the expectations of business firms would be disappointed. In either case, forces would be released that would push the system in the direction of the $\$ 20$

\& This assumption is not essential to the Keynesian system; I make it here in order to simplify the exposition. The figures used throughout are merely illustrative. Further, the exposition is restricted to the proximate determinants of employment in Keynes' system; this simplification does not affect the argument that follows. (This note appeared in the original essay.) 
billion mark. Hence, in the given circumstances, $\$ 20$ billion is the equilibrium income, and it may be concluded that the basic datathat is, the volume of investment and the consumption functiondetermine a national income of unique size. If we assume, now, a unique correlation between income and employment, it follows that the basic data determine also a unique volume of employment-which may turn out to be well below 'full' employment."'

This theoretical sketch can be readily translated into the language of diagrams, and it may perhaps prove helpful to some readers if I do that. In Figure 1 line $C C^{\prime}$ represents the consumption

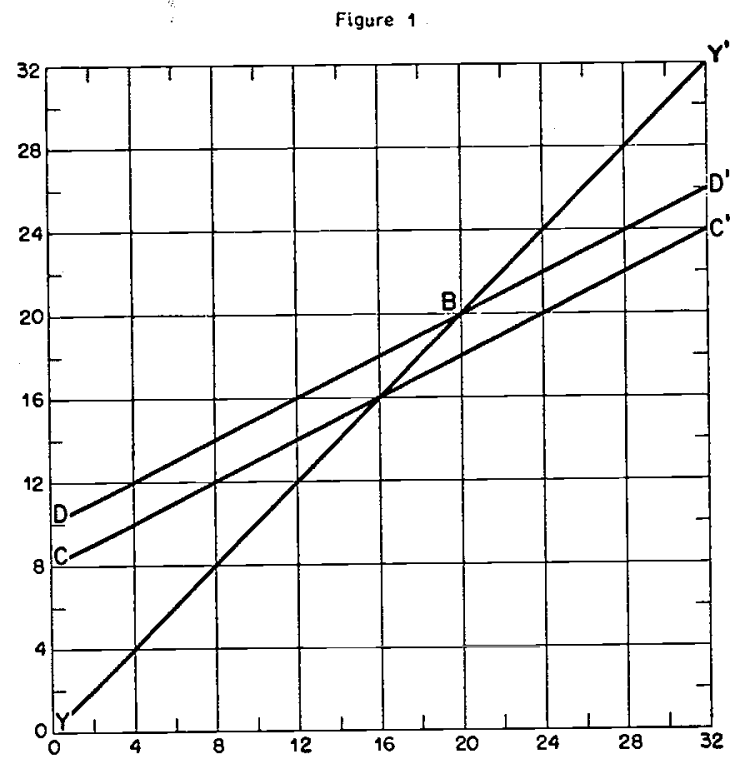

function, or the propensity to consume at levels of income specified along the horizontal axis. $D D^{\prime}$ represents the aggregate demand-that is, consumer outlay plus intended investment-at the specified levels of income. ${ }^{5} Y Y^{\prime}$ represents the aggregate supply function-that is, the sum that is just sufficient to induce business firms to pay out to the factors of production each sum along the horizontal axis. At $B$ income payments are 20 and $D D^{\prime}$ equals $Y Y^{\prime}$. At lower levels of income $D D^{\prime}$ exceeds $Y Y^{\prime}$; at higher levels $D D^{\prime}$ is less than $Y Y^{\prime}$. Hence, as said above, "if income payments

4 Keynesian Thinking, pp. 5-6. In later paragraphs, I distinguished between this general theory of income and employment, and its characteristic special variant-the theory of secular stagnation.

- Of course, $D D^{\prime}$ and $C C^{\prime}$ need not be linear; see note 3 . 
fell below $\$ 20$ billion, the sales expectations of business firms would be exceeded; while if income payments rose above $\$ 20$ billion, the expectations of business firms would be disappointed. In either case, forces would be released that would push the system in the direction of the $\$ 20$ billion mark." Figure 2 illustrates

Figure 2

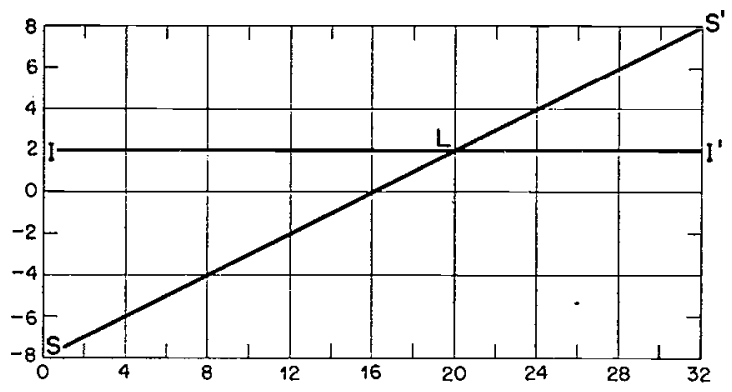

the same relations in another way. Here $I I^{\prime}$ represents the volume of intended investment, and $S S^{\prime}$ the propensity to save at specified incomes. At $L$ income payments are 20 and the intended investment equals the propensity to save. At other levels of income, the two are unequal. Since, in the given circumstances, any discrepancy between $I I^{\prime}$ and $S S^{\prime}$ merely expresses in a roundabout way the excess of $D D^{\prime}$ over $Y Y^{\prime}$, any deviation of income from $L$ will set forces in motion that will tend to restore this level of income. Hence $L$, or the point of intersection of $I I^{\prime}$ and $S S^{\prime}$, defines the equilibrium income. And since employment and income are assumed to be uniquely correlated, it defines also a unique volume of employment.

Turning now to Hansen's paper, I am forced to point out that Hansen has not made a single explicit criticism of the substance of my summary of Keynes' theory. Hansen begins by saying that I depart seriously from Keynes' terminology [in using the term 'planned' or 'intended' investment]. He then makes miscellaneous remarks, some of them critical of certain portions of my essay, but says nothing in explicit criticism of pages $5-7$, where I summarize Keynes' theory of income determination. If my terminology were all that troubled Hansen, there would be no cause for concern. For when I speak of 'planned' or 'intended' investment, I imply merely that 'actual' investment may be something different; I do not imply that it will be different. If the reader will substitute 'actual' for 'intended' whenever I refer to 
'intended investment,' ${ }^{\circ}$ he will discover that the only consequence is that business firms can no longer experience surprises with regard to their inventories. My sketch of Keynes' theory is perfectly general on this point-that is, I deliberately do not specify whether surprises are absorbed in price changes or in inventory movements. Hence anyone who wishes to rule out unintended changes in inventories, regardless of the fact that Keynes himself did not, ${ }^{7}$ is entirely free to do so. This restriction will make the Keynesian theory less general; it will have no other effect. ${ }^{8}$

Can it be, then, that Hansen's trouble is not merely my terminology: that despite his failure to specify error, Hansen feels that my summary sketch misses something vital in Keynes' theory of income? There can be no serious doubt on this matter. Hansen says more than once that I have failed to present Keynes' theory accurately, and actually makes an effort-I wish it had been more systematic-to put down his own understanding of the theory. The drift of Hansen's thinking on Keynes' theory of income is indicated by statements such as these: "With an initial income of $\$ 16$ billion, with new investment of $\$ 2$ billion, and with a marginal propensity to consume of $1 / 2$, income would rise to $\$ 20$ billion." "Investment actually made in fixed capital was presumably intended,' while part of the net investment in inventories may at times be 'unintended.' In any event, the actual investment in any given period is the relevant factor" for income determination. "As time unfolds from day to day, the rate of investment at any moment is a given amount; and whatever that given amount is, the flow of income is affected by the magnitude of the actual rate of investment. . . Thus, as the flow of investment unfolds, income rises or falls by a magnified amount according to the actually prevailing marginal propensity to consume" (my italics).

6 At one point I speak of 'planned investment' in an equivalent sense.

7 See General Theory, for example, pp. 123-124, 288.

8 To illustrate in terms of the preceding example: Assume that income payments are $\$ 24$ billion. This would imply that business firms expect to recover $\$ 22$ billion through the sale of consumer goods and to add $\$ 2$ billion worth to their stockpiles. The consumption function being what it is, they can recover only $\$ 20$ billion from the public. Under the present restrictive hypothesis they cannot absorb the difference by leaving an extra $\$ 2$ billion worth on the shelf; hence (barring destruction of unwanted goods), they must slash prices. The outcome for the given period is as follows: consumption, 20; investment, 2 ; income, 22; income payments, 24; con. sumer saving, 4 ; business dissaving, 2; aggregate saving, 2 . In the next period, investment being a datum, business firms will presumably curtail the output of consumer goods. And so they would also under the less restrictive hypothesis; that is, if inventories in the given period piled up, or if the failure of expectations to be realized led partly to price cuts and partly to a piling up of inventories. 
Now the remarkable thing about this representation of Keynes is that Hansen does not feel impelled to say anything about an economic process whereby one level of income supplants another, that he eschews all analysis of expectations or motivation, that he omits any reference to incentives that may induce business firms to maintain employment at one level or to shift from that level to some other; in short, that he sees no need for inquiring whether the balance of forces is such as to produce an equilibrium. He says blandly that if investment rises by $\$ 2$ billion, and the marginal propensity to consume is $1 / 2$, income will rise by $\$ 4$ billion. Given equality between saving and investment, this statement is, of course, arithmetically incontrovertible. But so also is the proposition that if income rises by 4 and the marginal propensity to consume is $1 / 2$, then investment must have risen by 2 . If the first statement expresses Keynes' theory of income determination, as Hansen seems to suggest, then by parity of reasoning the second expresses a theory of investment. And indeed, if it were as simple as all this, we would have at hand a veritable machine for grinding out theories on significant economic problems. Thus if we craved a theory of the propensity to consume, we could find it in the suppressed syllogism that if investment rises by 2 and income by 4 , the marginal propensity to consume must be $1 / 2$.

There is something-one might say a good deal-in Keynes to support such tautological propositions, but it is a little strange to find a devoted follower of Keynes giving them prominence. Obviously, Hansen is echoing one of Keynes' theories of the multiplier -specifically, "the logical theory of the multiplier, which holds good continuously, without time-lag, at all moments of time."s Need I say that Hansen is not honoring Keynes by identifying this unfortunate appendage of the General Theory with Keynes' theory of income? While Keynes at time lapses into tautologies, there can be no doubt that he sought to explain the level of income and employment in terms of underlying human motives and expectations. In seeking to establish "what determines the volume of employment at any time," 10 Keynes recognized that a solution requires proof. He therefore attempted to show that the factors isolated by his theory were sufficient to establish a "unique equilibrium value" of income and employment; that is, a value "at which there is no inducement to employers as a whole either to expand or to contract employment."11 When the task was done, Keynes

- General Theory, p. 122.

11 ibid., pp. 26, 27.

10 ibid., p. 319 . 
felt justified in remarking that the General Theory offered, "properly speaking, a Theory of Employment because it explains why, in any given circumstances, employment is what it is."12

In condensed and nontechnical prose, Keynes' proof is simply the sketch that I gave in my essay on Keynesian Thinking. In this proof two propositions are crucial, and both relate to the consumption function. The first is that consumption is a fairly stable function of income in experience; hence, what is actually a fuzzy band may be treated, for analytic purposes, as narrowing to a line. This proposition fixes the consumption function as such, and sets the stage-so to speak-on which investment can play. The second proposition is that as income expands, consumption also increases but by less than the increment of income. This proposition limits the shape of the consumption function. It is necessary if an equilibrium solution is to emerge, just as the first proposition is needed if the equilibrium is to have some relevance to the actual world.

Let Keynes now speak for himself: "The amount of labor . . which the entrepreneurs decide to employ depends on . . . the amount which the community is expected to spend on consumption, and ... the amount which it is expected to devote to new investment. ... When our income increases our consumption increases also, but not by so much. The key to our practical problem [i.e., what determines the level of income and employment] is to be found in this psychological law." 13 But why is this the key to the problem? Let Keynes continue: "What the theory shows is that if the psychological law is not fulfilled, then we have a condition of complete instability. If, when incomes increase, expenditure increases by more than the whole of the increase in income, there is no point of equilibrium. Or, in the limiting case, where expenditure increases by exactly 100 per cent of any increase in income, then we have neutral equilibrium, with no particular preference for one position over another. Neither of these conditions seems to be characteristic of the actual state of affairs. . ."14 Keynes' meaning is conveyed simply by Figure 1. Given the "psychological law," $D D^{\prime}$ must be (as drawn) above $Y Y^{\prime}$ to the left of $B$ and below $Y Y^{\prime}$ to the right of $B$. It follows that profits of entrepreneurs as a class will be maximized at the point of intersection of $D D^{\prime}$ and $Y Y^{\prime}$; that is, when income is the abscissa of $B$. Given

12 J. M. Keynes, "The General Theory of Employment," Quarterly Journal of Economics, February 1937, p. 221. 'The italics are Keynes'.

13 General Theory, pp. 29-30. My italics.

14 See Keynes' letter to Elizabeth Gilboy, Quarterly Journal of Economics, August 1939 , p. 634. The italics are Keynes'. Cf. General Theory, pp. 117, 118, 251-252. 
the propensity to consume and the intended investment, any erratic displacement of $B$ is self-restorative; that is, $B$ defines a position of maximum profit, or of stable equilibrium. But if the marginal propensity to consume exceeded unity, the slope of $D D^{\prime}$ would exceed that of $Y Y^{\prime}$; hence $D D^{\prime}$ would cut $Y Y^{\prime}$ to the left of $B$ from below. Any displacement of $B$, whether erratic or systematic, would now be cumulative; in other words, profit-seeking entrepreneurs would drive the system to full employment or to extinction, depending on whether the displacement was to the right of $B$ or to the left.

It should now be clear that Hansen's purely arithmetic reasoning $^{15}$ fails to convey Keynes' fundamental meaning. It is possible, however, to bring the one into harmony with the other. First, the "actually prevailing marginal propensity to consume," if it is to be taken as a historical datum at all, must be treated as a property of a stable consumption function; for, otherwise, it cannot have causal significance. Second, the marginal propensity to consume must be less than unity. Hansen reasons that if the initial income were 16 , new investment 2 , and the marginal propensity to consume $1 / 2$, income would rise to 20 . If the Keynesian theory of income were reducible to a formula of this type, we should have to say that if the marginal propensity to consume were $3 / 2$, other circumstances of the case remaining unchanged, income would fall to $12 .{ }^{16}$ This statement, arithmetically, is on a par with the preceding one. But whereas the first statement makes economic sense in Keynes' basic scheme, the second does not; for, as we have just shown, new investment in the second case will set off a cumulative movement that in real terms has no stopping point short of full employment, and in monetary terms no stopping point whatever. ${ }^{17}$

15 I am referring to Hansen's explicit argument. He may well have taken some things for granted.

1e To explain: Since new investment is 2 , a reduction of income by 4 and of consumption by 6 is necessary to satisfy the assumption that the marginal propensity to consume is $3 / 2$. In a more technical jargon, if the marginal propensity to consumer is $3 / 2$, the marginal propensity to save is $-1 / 2$, and the investment multiplier -2 ; hence, if investment goes up by 2 , income must come down by 4 .

17 Keynes was an extraordinarily effective teacher, but a poor pedagogue. A good one would have defined the stability conditions of his system with some care. It is not necessary to assume (though there is a gain in realism in doing so) that the marginal propensity to consume is greater than zero and less than unity (General Theory, p. 96); it is sufficient to assume that it is less than unity. If the marginal propensity exceeded unity, the system would be completely unstable, as Keynes states. If the marginal propensity equals unity, three cases are possible: neutral equilibrium as defined in the quotation in the text (i.e., when $I^{\prime}=S S^{\prime}$ for all values of income 
I have only one additional comment at this juncture. Hansen advises the reader to "compare the highly rigid picture which he gets from the discussion of the Keynesian determinants of income as stated in Burns' pamphlet, with the flexible treatment found" in different portions of the General Theory. If by this warning Hansen means merely that my summary fails to convey much that is contained in Keynes' book, I of course agree. My summary was designed to convey the "theoretical skeleton that underlies the Keynesian system," 18 not as an abstract of the General Theory. ${ }^{19}$ There are, to be sure, numerous and enlightening asides and qualifications throughout the General Theory. But Keynes was much inclined to operate with the bare bones of his system, and the Keynesians have done so preponderantly. My summary represents rather faithfully, I think, the analytic foundation on which the Keynesian school has built its theories, prognoses, and programs.

\section{The Determinacy of Keynes' Theory}

My essay on Keynesian Thinking carried a warning against what I consider to be the oversimplified doctrines of Keynes, especially as they are being used by his more zealous followers. I asserted

in Fig. 2), progressive inflation (when $I I^{\prime}$ exceeds $S S^{\prime}$ by a constant), and progressive deflation (when $S S^{\prime}$ exceeds $I I^{\prime}$ by a constant). Keynes doubtless was aware of these possibilities. Thus he writes: If the public seeks "to consume the whole of any increment of income, there will be no point of stability and prices will rise without limit" (ibid., p. 117). This statement does not contradict the quotation in the text; the two treat of different cases in the event of a marginal propensity of unity. But both statements also illustrate Keynes' carelessness about proper qualifying clauses (cf. ibid., p. 261). This, indeed, is the main reason why the General Theory is diffcult and so frequently misunderstood.

18 Keynesian Thinking, p. 6.

${ }_{10}$ The proper comparison is with the summaries of fundamentals sketched by Keynes himself, not with the parts of the General Theory selected by Hansen (though I hope that these parts as well as the rest of the treatise will receive the reader's attention). I refer to pages 25-30 of the General Theory, and to pages 219-221 of Keynes' paper in the February 1937 number of the Quarterly Journal of Economics. See also pages $247^{-249}$ of the General Theory (contained in one of Hansen's recommendations), though this summary is less successful in exposing the skeleton of the system than the summaries just cited. Cf. the following: A. P. Lerner, "Mr. Keynes' General Theory of Employment," International Labor Review, October 1936, especially pp. 446-447; P. A. Samuelson, "The Stability of Equilibrium: Comparative Statics and Dynamics," Econometrica, April 1941, pp. 113-120, and "Lord Keynes and the General Theory," ibid., July 1946, especially pp. 192, 199; O. Lange, "On the Theory of the Multiplier," ibid., July-October 1943, pp. 227-228; L. Klein, "Theories of Effective Demand and Employment," Journal of Political Economy, April 1947, pp. 109-117, and the review in the same, pp. 168-170; L. Tarshis, The Elements of Economics (Hough ton Mifflin, 194.7), Part rv, especially pp. 346, 360-365. (As far as I know, the sympathy of these authors for Keynes is not suspect.) 
that the widespread opinion "that Keynes has explained what determines the volume of employment at any given time ... reflects a pleasant but dangerous illusion." 20 After pointing out the essentials of the Keynesian theory and its structural similarity to the Ricardian model, I made the following comment:

“. . . Let us go back to the theoretical skeleton of the Keynesian system and examine it more carefully. Suppose that the volume of intended investment is $\$ 2$ billion, income payments $\$ 20$ billion, and consumers' outlay at this level of income $\$ 18$ billion. On the basis of these data, the economic system is alleged to be in equilibrium. But the equilibrium is aggregative, and this is a mere arithmetic fiction. Business firms do not have a common pocketbook. True, they receive in the aggregate precisely the sum they had expected, but that need not mean that even a single firm receives precisely what it had expected. Since windfall profits and losses are virtually bound to be dispersed through the system, each firm will adjust to its own sales experience, and within a firm the adjustment will vary from one product to another. Under the circumstances the intended investment cannot-quite apart from 'autonomous' changes-very well remain at $\$ 2$ billion, and the propensity to consume is also likely to change. Our data therefore do not determine a unique size of national income; what they rather determine is a movement away from a unique figure. Of course, we cannot tell the direction or magnitude of the movement, but that is because the basic data on which the Keynesian analysis rests are not sufficiently detailed for the purpose.

"I have imagined that Keynes' aggregative equilibrium is realized from the start. But suppose that this does not happen; suppose that, in the initial period, the intended investment is $\$ 2$ billion, income payments $\$ 16$ billion, and that savings at this level of income are zero. Will income now gravitate towards the $\$ 20$ billion mark, as the theory claims it should? There is little reason to expect this will happen. In the first place, windfall profits will be unevenly distributed, and the adjustment of individual firms to their widely varying sales experiences will induce a change in the aggregate of their intended investment. In the second place, unemployed resources will exercise some pressure on the prices of the factors of production, and here and there tend to stimulate investment. In the third place, if an expansion in the output of consumer goods does get under way, it will induce additions to inventories for purely technical reasons; further, the change in

${ }^{20}$ Keynesian Thinking, pp. 4-5. 
the business outlook is apt to stimulate the formation of new firms, and to induce existing firms to embark on investment undertakings of a type that have no close relation to recent sales experience. In the fourth place, as income expands, its distribution is practically certain to be modified; this will affect the propensity to consume, as will also the emergence of capital gains, the willingness of consumers to increase purchases on credit, and the difficulty faced by consumers in adjusting many of their expenditures to increasing incomes in the short run. These reactions, and I have listed only the more obvious ones, are essential parts of the adjustment mechanism of a free enterprise economy. Under their impact the data with which we started-namely, the amount of intended investment and the consumption function-are bound to change, perhaps slightly, perhaps enormously. It is wrong, therefore, to conclude that these data imply or determine, even in the sense of a rough approximation, a unique level at which the income and employment of a nation will tend to settle. In strict logic, the data determine, if anything, some complex cumulative movement, not a movement towards some fixed position.

"If this analysis is sound, the imposing schemes for governmental action that are being bottomed on Keynes' equilibrium theory must be viewed with skepticism. It does not follow, of course, that these schemes could not be convincingly defended on other grounds. But it does follow that the Keynesians lack a clear analytic foundation for judging how a given fiscal policy will affect the size of the national income or the volume of employment." ${ }^{21}$

This criticism can be summed up in a sentence: viz., the consumption function and the volume of intended investment, which are impounded in ceteris paribus by the Keynesian theory, cannot (except by accident) remain constant, since the very process of adjusting to the data (the consumption function and the volume of intended investment) will, quite apart from independent influences that may operate on these data, induce changes in them. Nevertheless I have thought it well, for reasons that will become apparent, to reproduce the original criticism in full.

Hansen observes that if my criticism simply means "that there are dynamic effects of the approach to equilibrium," that much had already been "admirably stated" by Keynes. I do not think it worth while to dwell on this comment. ${ }^{22}$ The important thing is

21 ibid., pp. 8-9.

22 However, I wish to note, first, that Hansen gives no reference to Keynes' statement; second, the faint suggestion on page 249 of the General Theory (if this is the 
Hansen's attempt to dismiss the criticism on the ground that it is not basic. Hansen does not argue the case directly, but proceeds by analogy. He invites attention to Taussig's "temperate remarks concerning the "penumbra' area of price determination," and informs the reader that Taussig's "highly interesting comments, elaborating dynamic aspects of the problem, were, however, not believed by Taussig himself to be damaging to the Marshallian theory of supply and demand." The reader is left to infer that my criticism, which elaborates dynamic aspects of the income problem, is likewise not damaging to Keynes' theory of income. And has not the reader been gracefully prepared for this inference by Hansen's earlier remark that the substance of my criticism had been "admirably stated"-_and presumably properly handled-by Keynes himself?

I can explain Hansen's dialectical feat only on the ground that he has not fully understood my argument. ${ }^{23}$ I shall therefore try again, and this time guard against deceptive analogies. Let us consider the output of a firm operating under conditions of pure competition. With minor modifications, Figure 2 will serve as an illustration of the case. Assume that the horizontal line $I I^{\prime}$ represents the demand curve facing the firm, and that the rising line $S S^{\prime}$ (the vertical scale being adjusted to eliminate negative values)

statement Hansen has in mind) hardly covers the case; third, it would be impossible to show, on the basis of citations from Keynes, that he submitted his work to the criticism I make; fourth, while Hansen's phrasing of my criticism (in view of the surrounding text) suggests that, in a general way, he has grasped my meaning at this point, it is not the phrasing I would use. (I should not speak of "dynamic effects of the approach to equilibrium," since the very point of the argument is that there are no good theoretical reasons for believing there will be such an approach.)

23 Of that there is some evidence, apart from what $I$ say in the text and in the preceding note. (1) When I assert that "our data ... do not determine a unique size of national income," Hansen inquires "what data?" The answer is the consumption function and the intended investment assumed in my example. (2) In commenting on my illustrative figures Hansen fails to notice that, when I suppose that "in the initial period, the intended investment is $\$ 2$ billion, income payments $\$ 16$ billion," etc., I explicitly proceed from a position of disequilibrium. (3) Hansen asserts that he is "forced to disagree both on the basis of theoretical and statistical studies" if, in questioning the determinacy of the Keynesian theory of income, I believe "that the consumption schedule and levels of actual investment must be moved capriciously by the dynamic process of adjustment" (my italics). I am puzzled how Hansen could have imagined I meant any such thing, since $I$ at no time referred to capricious movements but did suggest that the "data" determine a cumulative movement.

A parenthetic item remains: what theoretical and statistical studies does Hansen have in mind? I do not know of any statistical studies that indicate absence of capricious shifts in the consumption function. It seems to me that it is exceptionally diffcult to determine short-run shifts (other than seasonal) of the consumption function empirically, and that this seriously limits the effective use of the Keynesian analytical apparatus for many problems of short-run economic change. 
represents the marginal cost of different possible quantities of its output (indicated on the horizontal axis). According to the standard theory, these data suffice to determine the output of the firm in "the short run." The solution is indicated by the abscissa of the point of intersection of $I I^{\prime}$ and $S S^{\prime}$, which in our diagram is 20. The proof is simple. If output were smaller, an extra unit of output would add more to revenue than it would to costs; while if output were greater, a reduction of output by one unit would cut costs more than revenue. Since profit is at a maximum when output is 20 , any deviation from that figure will stimulate a movement towards it. In this sense output is uniquely determined.

Within its own framework, this theory of the firm is strictly valid. There is nothing in the situation surrounding the indicated equilibrium output that could of itself induce changes in the demand curve facing the firm (the market price) or in its schedule of marginal costs. Hence the theory cannot be challenged on the ground that if output happened to be at the indicated equilibrium value, it could not be maintained. Nor can the theory be challenged on the ground that if output happened to be out of equilibrium, the process of adjusting to the data-that is, to the demand and supply schedules of the firm-would of itself modify these data. Any criticism along these lines would overlook the condition of pure competition-which reduces the firm to an atom. To be sure, as output varies, there will be changes in the resources employed and in income payments. But since the firm can have only a negligible influence on the demand for resources or on the industry's output, it cannot perceptibly influence any price; in other words, the demand curve facing the firm and its schedule of marginal costs can remain virtually intact as its output undergoes variation.

Let us now return to Keynes' theory of income. In essence, it is an extension of demand and supply analysis to output as a whole. The vital factors in this analysis are the consumption function and the intended investment. These are the data to which business firms, in the aggregate, are supposed to adjust. These are also the data that the theory impounds. But processes of reasoning that are valid for the output of a single firm or small industry cannot be carried over mechanically to output as a whole. Indirect effects can be ignored or slighted in the case of an economic atom, but not for the economy taken as a whole. Infinitesimal adjustments, which might still save the situation formally, are of no practical relevance. By failing to analyze the far-flung repercussions of ad- 
justment processes, Keynes' theory of aggregate income moves on a superficial level, and misrepresents the forces at work. This is the upshot of the criticism of the determinacy of this theory, quoted at the beginning of this section. To dispose of the criticism it would be necessary to show that the induced changes in the consumption function and intended investment are inappreciable, or that they are self-correcting even if large. I suggest that the reader, whether or not he thinks the criticism justified, now turn back and see whether Hansen has come to grips with the issue. ${ }^{24}$

While I concluded in my essay that Keynes has failed to justify his claim of explaining what determines the volume of employment at any given time, I did not claim that my criticism was decisive. Let the reader note carefully the following sentences, which express the essence of what I tried to convey in the essay: "The problem of unemployment facing our generation calls for realistic, thorough, and unceasing investigation. The great and obvious virtue of the remedies proposed by the Keynesians is that they seek to relieve mass unemployment; their weakness is that they lean heavily on a speculative analysis of uncertain value. This weakness attaches also to my critical remarks on the theory of underemployment equilibrium. Granted that the simple determinism of Keynesian doctrine is an illusion, it does not follow that secular stagnation is another, or that the consumption function may not be sufficiently stable in experience to enable public officials to forecast reliably some consequences of their policies. These questions raise factual issues of the highest importance. . . ." ${ }^{25}$

\section{The Keynesian Consumption Function}

I have already suggested how important the consumption function is in Keynes' scheme. This was emphasized in Keynesian Thinking, where I argued that the consumption function occupies much

\footnotetext{
24 The Taussig analogy, as used by Hansen, skirts essentials: (1) Taussig assumed that the underlying conditions of demand and supply in a given industry were independent of adjustment processes. Can a similar assumption be reasonably made for the economy as a whole? (2) Taussig did not assume independence in the short run; on the contrary, he emphasized changes in the "data" induced by adjustment processes. If this much be granted for the Keynesian theory, can it be claimed that it explains what determines income and employment at any given time? (3) Taussig considered the indeterminacy of the Marshallian price theory in the short run (days or weeks or months) a matter of real importance. Can it be argued that the indeterminacy of the Keynesian income theory in its short run (surely a longer span) is of slight consequence? (See F. W. Taussig, "Is Market Price Determinate?" Quarterly Journal of Economics, May 1921, especially pp. 401, 402, 405, 411. Compare the passages quoted by Hansen with Taussig's conclusion in full.)

25 Keynesian Thinking, pp. 10-11.
} 
the same place in Keynesian economics as the agricultural production function in Ricardian economics. Since the Ricardian parallel is not immediately relevant, I shall confine quotation to the passages on Keynesianism: "The most important proposition in Keynesian economics is that the consumption function has a certain shape, that is, consumer outlay increases with national income but by less than the increment of income. . . The Keynesians treat the consumption function as fixed, and deduce the effects on the size of the national income of an increase or decrease in private investment, or of an increase or decrease in governmental loan expenditure. . . . To be sure, the . . Keynesians . . recognize that the consumption function is not absolutely rigid, and they frequently insert qualifications to their main conclusions. But I have formed the definite impression that the Keynesians-except when they discuss changes in personal taxation_attach even less importance to their qualifications than did the Ricardians. . . ."26

I have put in italics the words singled out by Hansen as evidence of my "misconceptions" with respect to the consumption function. That these words do not suffice to convey my meaning is evident from the context in which they appear. I charged the Keynesians with minimizing the importance of shifts in the consumption function; I did not claim that Keynes or his followers believe that the consumption function is "fixed." Once more, I do not say merely that Keynesian economics postulates a "certain shape" of the consumption function. The rest of the sentence, which identifies the meaning of "certain shape" reads: "that is, consumer outlay increases with national income but by less than the increment of income." Since this is nothing other than Keynes' 'psychological law,' which in Keynes' own words ${ }^{27}$ is the "key" to the problem of income determination and "absolutely fundamental" to his theory, is it not strange that Hansen sees a misconception in my statement?

The best interpretation I have been able to put on Hansen's strictures is that he is concerned less with what I actually say about the Keynesian treatment of the consumption function ${ }^{28}$ than with

26 ibid., p. 7 (italics added).

27 General Theory, p. 29, and "The General Theory of Employment," op.cit., p. 220.

28 Thus Hansen alleges other misconceptions of Keynes' views (or is it the views of Keynesians?) "about these matters," and quotes four statements from pages 9-10 of my essay as evidence. By "these matters" Hansen is apparently referring to the consumption function, since that is the subject he is discussing. But three of the quoted statements do not even relate to the consumption function (for example, the statement that "monopolistic practices of business firms can safely be neglected"). Hansen also 
the general drift of my remarks. I suspect that Hansen is troubled because my essay conveys the impression that the Keynesians are excessively mechanical in their thinking, that they gloss over the turbulent life that goes on within aggregates, that they give little heed to adjustment processes in our society, that they subject ceteris paribus to excessive strain, that they slight in particular the instability of the consumption function; and that while Keynes is guilty on all these counts, the Keynesians-among whom Hansen is outstanding-are guiltier still. If that is what is troubling Hansen, I do not think the fault is mine.

claims there is a misconception-or is it misconceptions?-on page 19 , but fails to specify what it or they are.

The four statements on pages 9-10 which Hansen construes as misconceptions "about these matters" are lifted (a bit inaccurately) from my analysis of the types of assumption needed to reach a conclusion-of which much has been made lately by Keynesian writers-concerning different fiscal paths to 'full employment'; namely, that the loan-expenditure method "avoids ... the excessively large expenditures" of the tax-financing method "and the excessive deficits" of the tax-reduction method (Keynesian Thinking, p. 9). This conclusion is advanced, among others, by Hansen in "Three Methods of Expansion through Fiscal Policy," American Economic Review, June 1945. Since Hansen did not indicate how he reached this "highly suggestive conclusion" (Keynesian Thinking, p. 9), I tried in my essay to pin down the theoretical steps that would lead rigorously to his assertions, and that apparently underlie them. My analysis may be right or it may be wrong; instead of dealing with it, Hansen amasses phrases without regard to the context, and declares they are misconceptions "about these matters"-by which he seems to mean the consumption function, though what he actually means is uncertain.

However, Hansen makes one comment (later and quite incidentally) that possibly relates to this fiscal analysis. The comment begins as follows: "The last paragraph on page 7 relating to recent developments in income theory discloses a mistaken view with respect to the nature of these contributions." (In the paragraph cited, which runs over a page in length, just two sentences bear on recent developments in income theory: "Of late this theory [of the Keynesians on employment policy] has been refined and elaborated, so that 'deficit financing' need no longer be the key instrument for coping with unemployment, and I shall refer to one of these refinements at a later point [this comes on pages $9^{-10}$ of the essay]. But the practical significance of the modifications of the theory is problematical, and in any event the theory as I have sketched it still dominates the thinking of the Keynesians when they look beyond the transition from war to peace" [italics added].) Hansen then refers to Haavelmo's paper on "Multiplier Effects of a Balanced Budget" (Econometrica, October 1945), which takes for granted "that expenditures financed by progressive taxation (effecting a redistribution of income) may raise income," and goes on to discuss (as do the papers it stimulated) "the question whether tax-financed expenditures may be expansionist even though there is no redistributional effect upon the propensity to save." Hansen stops abruptly at this point. The best $I$ can make of this incomplete argument is that Hansen sees an inconsistency between my method of handling the effects of taxation on the propensity to consume on page 10 of the essay and Haavelmo's method. But there is no inconsistency, since my schedule of the propensity to consume is tied to income before taxes (as is Hansen's in "Three Methods of Expansion through Fiscal Policy," op.cit.), while Haavelmo's is tied to disposable income. 
Keynes says quite definitely: ". . . we are left with the conclusion that short-period changes in consumption largely depend on changes in the rate at which income (measured in wage-units) is being earned and not on changes in the propensity to consume out of a given income." ${ }^{29}$ Keynes did not stop with this generalization. $\mathrm{He}$ proceeded to build a system from which "changes in the propensity to consume" were excluded. To be sure,.. the "changes" are brought in, now and then, by way of qualification. They are also brought in, now and then, in comments on policy. But they do not enter the grand theorems. The 'blade' of investment carves out economic fortune; the 'blade' of the propensity to consume remains stationary while the carving is done. Or to change the metaphor, investment is the actor in the drama of employment, and the consumption function is the stage on which this actor-a rather temperamental one-performs his antics. Why is national income a function of investment? Why is Keynes equipped with an investment multiplier, which accomplishes wonders, but does not even mention a consumption multiplier? Why should an extra Ford car fructify income if acquired for business use, but not if acquired for pleasure? To these questions there is only one logical answer: In Keynes' scheme investment is a free variable, while consumption is rigidly and passively tied to income. ${ }^{30}$

But what of Hansen's views on the consumption function? Taking his extensive writing of recent years as a whole, ${ }^{31} \mathrm{I}$ feel that he is more prone to identify the formal Keynesian model with the operations of the actual world than was Keynes himself. To Keynes a stable consumption function is an analytic convenience, as I mentioned earlier. True, he sometimes loses sight of the restriction. But when he is explicitly engaged in empirical generalization, his characteristic phrase is a "fairly stable" function. To Hansen a stable consumption function seems to be a tight description

28 General Theory, p. 110 . Cf. ibid., pp. $95-97,248$. I do not believe that in expressing the consumption function in wage units, Keynes meant more than that consumption "is obviously much more a function of (in some sense) real income than of money-income" (ibid., p. 91, Keynes' italics). I do not know of any evidence that will support Hansen's tentative suggestion that Keynes meant to allow by this device for secular shifts in the consumption function. See Hansen's "Keynes and the General Theory," this Review, Vol. xxvir (1946), p. 184 .

so Samuelson has put the matter accurately: "The crucial assumption upon which it [the doctrine of the investment multiplier] stands or falls is that consumption expenditures and savings are rigidly related to the level of national income. The passive character of consumption cannot be sufficiently stressed." See his "Theory of PumpPriming Reexamined," American Economic Review, September 1940, p. $49^{8}$.

81 I have not, however, as yet examined with any care Hansen's recent book on Economic Policy and Full Employment (McGraw-Hill, 1947). 
of reality, at least in the short run. His characteristic phrase is "highly stable." The following is a typical specimen of his thinking on the subject: "There is no evidence that the cyclical consumption-income pattern has shifted, or is likely to shift in the near future, so as to increase consumption and reduce savings. . . . The fact is that, at moderately high income levels, persistent institutional factors determine within rather rigid limits the ratio of consumption to income. . . . The superficial view that the persistence of vast unsatisfied consumer wants is an answer to the problem of limited investment outlets-outlets inadequate to fill the gap fixed by the consumption-savings pattern-overlooks the stubborn fact that this pattern is, according to all the available evidence, a highly stable one. It is not likely to be radically changed from one decade to another except by important modifications in fundamental institutional arrangements. . . . But whatever the net trend ... there can be little doubt that no important shift in the consumption-income pattern can be expected within a short period. We have to recognize that we are dealing here with a function that is highly stable and is not easily changed." 32

In his present paper Hansen protests that he does not hold that the consumption function is "fixed." The above quotation would definitely support him in that statement. Hansen also protests that he does not hold that the consumption function is "practically invariant." Whether the quotation also supports that statement, I must leave to the readers' own sense of adjectival subtlety. Hansen protests that he has himself called attention to the upward secular shift in the consumption function, and indeed he has. He even grants that seasonal movements in the function "might conceivably ... be found to exist." ${ }_{33}$ All this is to the good. I prefer, however, to stick to the issue, which is not that the Keynesians regard the consumption function as fixed, but that they attach slight importance to its wanderings. ${ }^{34}$

I know of only three ways of testing the position of an author. The first is to determine whether his writing as a whole has a definite pattern. The second is to examine with special care what

32 Fiscal Policy and Business Cycles (Norton, 1941), pp. $247-249$ (my italics). See also ibid., pp. $62-63,237,238,250$.

33 Hansen's caution here is admirable, even if a little excessive. Of all the positive propositions that have been laid down in the literature on the consumption function, its seasonality is almost certainly the one that can be most firmly buttressed by statistical evidence on the American economy.

34 Except, perhaps, "when they discuss changes in personal taxation" (Keynesian Thinking, p. 7). 
he says when he attempts to sum up his own thinking. ${ }^{35}$ The third is to observe how he handles major economic problems. The last test is the most important of all. I judge that if shifts in the consumption function over the course of a business cycle seemed at all significant to Hansen, he would not assert unequivocally that "it is just because of the high stability of the consumption function that fluctuations in the rate of investment produce the business cycle:" ${ }^{36}$ Nor would he say, without further ado, that the "essence" of the depression of 1929-1932, "as indeed of all depressions, can quite simply and plainly be stated"; this essence being the decline in private capital outlays, which "caused unemployment in all the heavy goods industries, and in turn induced a decline in consumption expenditures."'s7 Again, I judge that if Hansen took the upward secular drift in the consumption function seriously, he would not have ignored it in his Presidential Address (American Economic Association, 1938), which dealt with the forces that shaped national income in the "nineteenth century" and how these forces have lost strength in "our times." In this important paper-still the fountainhead of stagnationist thinking-Hansen freezes the consumption function almost at the start, ${ }^{38}$ then (quite logically) maintains silence on its part in economic evolution.

3s See the above quotation, identified in note 32 , which comes from the concluding section of Hansen's fullest discussion of the consumption function, Chapter XI of Fiscal Policy and Business Cycles. I may add that much of that chapter seems to me to be in conflict with the conclusions quoted above.

36 ibid., p. 249 (my italics).

87 See Hansen's essay on "Stability and Expansion," in Financing American Prosperity, ed. P. T. Homan and F. Machlup (Twentieth Century Fund, 1945), p. 210 (my italics). On the stability of the consumption function, see also ibid., pp. 219,225 .

38 This is accomplished in a single sentence (which purports to sum up both the thinking of economists and the economic past): "Thus we may postulate a consensus on the thesis that in the absence of a positive program designed to stimulate consumption, full employment of the productive resources is essentially a function of the vigor of investment activity." This, of course, is the kernel of Keynes' short-run theory, and Hansen makes it serve a theory of long-run economic development. See page 372 of the Blakiston volume on Readings in Business Cycle Theory, where Hansen's paper on "Economic Progress and Declining Population Growth" is reprinted from the American Economic Review, March 1939.

Can it be that Hansen was not aware of the upward secular drift of the consumption function at the time he wrote this paper? His first mention of it, as far as I know, comes in Chapter XI of Fiscal Policy and Business Cycles (1941), p. 233. Chapter Xvil of that book reprints the Presidential Address, with various modifications. The sentence quoted at the beginning of this note does not appear in Chapter xvir. Was Hansen led to make the omission by what he says on page 233 ? If so, he must have felt that, as far as the consumption function was concerned, no further change was necessary; for he did not add one word on the role of the upward drift in the consumption function in economic development. (The new paragraph inserted on pages $357.35^{8}$ is of some interest in this connection.) 
There is much more that might be said of the manner in which the consumption function is handled by the Keynesian school, but I think I have gone far enough to indicate that the "rigid picture" of Keynesianism in my essay-while displeasing to Hansen-is painted from life. I wish merely to add a few methodological remarks on the consumption function per se, which is a schedule or curve relating aggregate consumption to aggregate income. If the curve is to mean more than a line on a piece of paper, time must somehow enter. It does so in three ways, as in a demand curve of the Marshallian type. First, the curve relates to a definite periodday, year, or something else. Second, both consumption and income are rates per unit of time, which of course need not be the same as the specified period. Third, the curve shows the response of consumption to income after a certain period of adjustment, which may be 'short' or 'long.' These simple observations have several significant implications: (a) The curve shows a relationship between hypothetical_not existential_magnitudes. (b) For any given period there is not one curve relating consumption to income, but a family of curves, each corresponding to a different period of adjustment. (c) Since there is no fast line ${ }^{39}$ between consumer and investment expenditure, another family of curves-one for each reasonable pair of definitions of income and consumption-corresponds to every member of the first family. (d) Finally, since tastes, technology, and resources keep changing in the world we know, the ensemble of curves may be expected to shift from one period to the next.

This, I think, expresses the essentials of the theoretical framework that faces the economist who seeks to determine the empirical properties of the Keynesian consumption function. Quite obviously, vigorous short cuts must be taken, if anything useful is to be accomplished on the problem. I take it as a reassuring sign of our times that the General Theory was promptly followed by efforts to measure the consumption function; that there was no gap of a quarter century, such as separated Moore from Marshall. But I feel that it is regrettable that some of the work has been

39 Keynes says that "any reasonable definition of the line between consumerpurchasers and investor-purchasers will serve us equally well, provided that it is consistently applied" (General Theory, p. 61). This is entirely proper for a formal system. But Keynes' "fairly stable" consumption function is not a property of his formal system; it is an empirical generalization, as is Hansen's "highly stable" function. Can the empirical properties of the aggregate consumption function be determined reliably without an analysis being made of the parts that make up the whole-especially the parts that shade into the volatile category of investment? 
done in haste, and that much of it has been used uncritically. Man is a slave not only to his theories, but to the very words in which theories are expressed. I venture the guess that if Keynes' theory had been worded in terms of a 'propensity to save' instead of a 'propensity to consume' (which would not of itself change the theory one iota), some of his doctrines would have fewer adherents today. My reason is simply that the evidence which seems to support a "stable" consumption function would less readily support a "stable" savings function.

\section{Keynesian Apparatus vs. Keynesian Theory}

A considerable part of Hansen's paper is devoted to methodological questions. Here I see no great issues raised. When all is said and done, there is no methodological problem in economics other than straight thinking and the competent use of evidence. The important question always is whether this or that theory is sound, not what role this or that investigator assigns to economic theory. I have, perhaps, more faith in the possibility of a science of economics than Hansen..$^{40}$ I surely think that economists should work unceasingly towards that end, and that they fail to do so when they grow impatient with their intractable material. I look forward to the day when economists will not rest content until they have at least specified the observable conditions that would contradict their theories, when the conformity of a theory to facts is respected no less than its logical consistency, and when carefully formulated theories are tested promptly and thoroughly in a score of research centers. But my views on economic methodology, such as they may be, are quite apart from the issues of Keynesian economics raised in my essay and so roundly challenged by Hansen. ${ }^{41}$

I do not see that Hansen's methodological comments have anything to do with the validity of Keynes' basic theory of underemployment equilibrium. Nevertheless, it may be worth while to clarify the distinction between "theory" and "theoretical apparatus" which seems to underlie Hansen's methodological remarks.

40 That does not mean I believe that massive statistical studies will provide us with "a definitive understanding of economic developments which is no longer subject to doubt by competent economists." See, for example, page 17 of Keynesian Thinking ("The data necessary to develop adequately the secular aspects of consumption and saving will not be easy to find or to interpret when found, but the importance of the question may justify our taking the risk") or page 24 ("True, the most painstaking studies of experience will not always lead to conclusive answers; but they should at least narrow the margins of uncertainty, and thus furnish a better basis than now exists for dealing with grave issues of business cycle theory and policy").

41 See above, note 1 . 
This distinction is blurred in Hansen's account, with the result that my views, if not also his own, are not represented accurately.

$I$ have no quarrel with the Keynesian theoretical apparatus as such, any more than with the Ricardian or Marshallian. The Keynesian theoretical apparatus is merely an analytical filing case for handling problems of aggregate income and employment, and is logically akin to Marshall's filing case for handling problems of price. Marshall's files are labeled 'demand' and 'supply,' and there are subdivisions in each on the 'length of the run.'42 Keynes' files are labeled 'propensity to consume,' 'marginal efficiency of capital,' 'liquidity preference,' and 'supply of money.' The usefulness of Marshall's files in facilitating orderly analysis of price problems is, I think, universally recognized. Keynes' filing case is a more brilliant construction; it is also more novel, and is still fighting its way. ${ }^{43}$ On its effectiveness in handling some problems, especially those of short-run change in income and employment, I happen to have serious doubts. ${ }^{44}$ But I should readily grant its promise for analyzing certain broad problems of economic organization and evolution, and I think that much more experimenting needs to be done before its range of usefulness can be justly appraised. ${ }^{45}$

But the Keynesian theoretical apparatus is one thing, the Keynesian general theory of income and employment is another, and the Keynesian theory of income and employment in the current institutional setting is still another. My essay was concerned with the second and third, not the first. I questioned the determinacy of Keynes' general theory on the ground that it proceeds on a tacit assumption that is open to grave doubt-namely, independence of the consumption function and intended investment from the

42 The sublabels on time are indistinct for demand, but I think they are there; in any case, they can be put there (as they can and should be throughout the Key-
nesian file).

43 No one questions Keynes' enormous influence, but there are better sources than gossip for ascertaining its extent. The files of the Economic Journal and other English periodicals do not support Hansen's report (based on what he heard from an unnamed English economist) that "every economist in Britain is now a Keynesian ... in the sense that all use the Keynesian terminology and the: Keynesian theo. retical apparatus."

44 I have in mind here the apparatus as a whole. Chapters 19 and 22 of the General Theory deserve very careful study from the viewpoint of the effectiveness of the Keynesian theoretical apparatus, as do also some later contributions-among them the treatment of business cycles in Tarshis, op.cit.

45 I have the impression that the Keynesian file itself is being recast: that the files on 'liquidity preference' and 'supply of money' are fairly inactive, and that the file on 'marginal efficiency of capital' now usually carries the label 'investment.' 
adjustment processes of a free enterprise system. If the criticism is valid, it bears also on the doctrine of secular stagnation, which I consider the characteristic expression of the Keynesian theory of income and employment in "our times." But two explicit assumptions of the stagnationist doctrine have a more vital bearing on its validity. The first is that "consumer outlay is linked fairly rigidly to national income and is unlikely to expand unless income expands," the second that "investment opportunities are limited in a 'mature' economy such as our own." 48 Since these assumptions raise factual issues of the highest importance, it surely is desirable to put them to a thorough test. "7 "A scientific theory cannot require the facts to conform to its own assumptions," and to urge this homely truth-I have now put it in Keynes' words ${ }^{48}$-is not to raise, as Hansen seems to believe, "important issues concerning the value and validity of theoretical analysis." 49

An economic theorist is justified on many occasions in oversimplifying facts to clarify in his own mind what he believes to be significant relationships. ${ }^{50} \mathrm{He}$ is likewise justified in bringing the results of his speculative inquiries before his colleagues, whether to seek their critical appraisal before going further or to stimulate them by his work. As long as the economist moves within these boundaries, he may be excused even for not making a strenuous effort to discover how seriously he has distorted the facts by his simplifying assumptions. But when he attempts to give practical advice, he loses his license to suppose anything he likes and to

46 Keynesian Thinking, p. 6.

47 See ibid., pp. 10-17.

48 General Theory, p. 276.

49 When I assert that "Keynes and his followers . . . by and large . . still seek to arrive at economic truth in the manner of Ricardo and his followers" (Keynesian Thinking, p. 4), I mean that the Keynesians manifest a strong tendency to take logical consistency with explicit assumptions as their criterion of economic truth and that this is insufficient, first, because the explicit assumptions may collide with facts of experience; second, because the tacit assumptions (they are always present) may do likewise. Hansen is not concerning himself with my views when he first interprets the above quotation to mean "searching for fruitful general hypotheses whose deductive implications are carefully assessed," then adds, "fortunately, this charge is indeed true as far as it goes."

Noting my statement on page 8 of the essay that "there is, of course, nothing unscientific about Ricardianism [i.e., the deductive method] as such," Hansen inquires why I wrote "the section dealing with "the fate of the Ricardian system." The an. swer is contained in the beginning words of the next sentence on that page: "But ceteris paribus is a slippery tool. . . " Hansen has apparently been misled by the phrase "the fate of the Ricardian system," which occurs at one point in the section on "The Lesson of Ricardianism." The context makes it plain (I think) that in that section I was concerned exclusively with Ricardo's dynamic theory (in Mill's sense), not with his static theory.

50 See Keynesian Thinking, pp. 9-10. 
consider merely the logical implications of untested assumptions. It then becomes his duty to examine with scrupulous care the degree in which his assumptions are factually valid. If he finds reason to question the close correspondence between the assumptions and actual conditions, he should either not undertake to give any practical advice, or frankly and fully disclose the penumbra that surrounds his analysis and the conclusions drawn from it. Better still, he should rework his assumptions in the light of the facts and see whether he is justified on this new basis in telling men in positions of power how they should act. Economics is a very serious subject when the economist assumes the role of counselor to nations.

I cannot agree with Professor Hansen that "the only realistic question is whether or not Keynes has given a fruitful direction to the study of income determination and employment." To this question a hearty affirmative is the only answer, but it is not the only realistic question. In view of the part that Keynes and his school have played in the theoretical and practical worlds, it is not unrealistic to inquire whether their theories bear out the claim that they explain what determines the volume of employment at any given time. ${ }^{51} \mathrm{I}$ do not think this claim could be readily accepted, even if my doubts concerning Keynes' general theory of underemployment equilibrium—or its special variant, the theory of secular stagnation-turned out to be baseless. Somehow the business cycle, and the various technical and institutional lags on which it so largely rests, would have to be brought into the theoretical system. But as Professor Hansen himself suggests, Keynes' theory of business cycles is a mere sketch, quite incidental to the theory of underemployment equilibrium. In my essay I had something to say about the loose relation between Keynes' thinking on business cycles and the facts of experience, and Professor Hansen has challenged my interpretation. While our differences on Keynes' business cycle theory must not be overlooked, they have practically no bearing on the Keynesian doctrines that have stirred the world, and $I$ therefore relegate this theme to an Appendix.

51 Hansen asks whether I meant to imply that various governments, "misled by Keynes, have embarked upon a mistaken policy" in announcing their assumption of responsibility for the maintenance of a high and stable level of employment (the quoted words are from Hansen's paper). I meant to convey merely that in view of the existing state of knowledge governments are assuming a responsibility they may be unable to discharge adequately; hence "the need for authentic knowledge of the causes of unemployment in modern commercial nations is now greater than ever" (Keynesian Thinking, p. 10). 


\section{Appendix on Keynes' Theory of Business Cycles}

After considering Keynes' theory of underemployment equilibrium and the issues of fact raised by the Keynesian doctrine, I went on to stress "the need for tested knowledge of business cycles." I tried to develop the simple but fundamental proposition that unless "precise and tested knowledge of what the business cycles of actual life have been like . . . is attained, any explanation is bound to bear an uncertain relation to the experiences we seek to understand or to guard against." Keynes' theory was brought in only incidentally, to illustrate "the consequences that may flow from a disregard of this elementary precaution." In a single paragraph I informed the reader of my purpose (just quoted), informed him also-on the chance that he did not already know it-that Keynes' theory is a "sketch" put "at the end of his long treatise on underemployment equilibrium," summarized the essentials of the sketch, and commented on its failure to square with experience. I then noted that "Keynes' adventure in business cycle theory is by no means exceptional. My reason for singling it out is merely that the General Theory has become for many, contrary to Keynes' own wishes, a sourcebook of established knowledge."'2

It will help to clarify the substantive issues if I reproduce my account of Keynes' point of departure: “Keynes starts by saying that a theory of business cycles should account for a certain regularity in the duration and sequence of cyclical phases-that the duration of contractions, for example, is about three to five years. Second, the theory should account for the sharp and sudden transition from expansion to contraction, in contrast to the gradual and hesitant shift from contraction to expansion." 3 I have placed in italics the phrases singled out by Hansen for criticism. They seem brittle to Hansen and inspire this conclusion: "The version of Keynes which Burns criticizes is a straw man; it cannot be found in Keynes."

But is not Hansen's verdict too sweeping? In reviewing the General Theory, Hansen had this to say about Keynes' view on the duration of cyclical contractions: "The carrying costs of surplus stocks is the second important factor, in Keynes' view, which determines the duration of depression. The carrying charges tend to force the absorption of surplus stocks within a certain period,

I See Keynesian Thinking, pp. 17-24.

2 ibid., p. 19. In reading Hansen's critique, the reader may find it useful to take cognizance of this background.

${ }^{3}$ Keynesian Thinking, p. 18 (italics added). 
usually within three to five years. While the process of stock absorption is going on there is . . . deflation and unemployment." 4 Hansen not only found in Keynes a contraction of about three to five years, but also that his theory was designed to explain the sharp and sudden transition from expansion to contraction. Hansen put Keynes' view as follows: "A complete explanation of the cycle must, moreover, involve an analysis of the crisis-the sudden and violent turning point from boom to depression." ${ }_{5}$ In a later paper, Hansen found once again the sudden transition, not in any straw man, but in Keynes. Hansen even nodded in approval: "The reason why the spurt comes to a sudden halt is well stated by Keynes in his chapter on the Trade Cycle when he says that the essential character of the Trade Cycle is mainly the result of the way in which the marginal efficiency of capital fluctuates." 8

I do not know Hansen's reasons for shifting his position, but I am reasonably confident that he was right the first time. When Hansen was trying to summarize Keynes' business cycle theory, he adopted the same interpretation that I did. The passages he now cites from Keynes are isolated remarks, which do justice mainly to Keynes' mischievous style; they do not convey his meaning faithfully. Take the following sentence by Keynes: "There is, however, another characteristic of what we call the Trade Cycle which our explanation must cover if it is to be adequate; namely, the phenomenon of the crisis-the fact that the substitution of a downward for an upward tendency often takes place suddenly and violently, whereas there is, as a rule, no such sharp turning-point when an upward is substituted for a downward tendency."7 Hansen lifts one clause (the words in italics) from this sentence. To be sure, this clause suggests that downturns are merely often abrupt; but the sentence as a whole, I think, suggests that downturns are as a rule abrupt. This is the interpretation Hansen put on Keynes originally, and it is also the interpretation against which the critical remarks in my essay were directed. ${ }^{8}$ And can there really

* See, for convenience, A. H. Hansen, Full Recovery or Stagnation? p. 33 (my italics).

s ibid., p. 32 (my italics). B ibid., p. $5^{1}$ (my italics).

7 General Theory, p. 314. (Italics mine. In Keynes' text, crisis is italicized.)

8 My statement that in Keynes' view "the theory should account for the sharp and sudden transition from expansion to contraction" can of course be read (as can the citations from Hansen just given) as implying that Keynes meant that downturns are invariably abrupt. Had I wished to convey this meaning, I need not have cited more than a single exception. Instead, I referred to Keynes' "rule," and cited several exceptions (four out of a possible seven during the period covered) to show that there was no such systematic difference between the upper and lower turning points as Keynes had supposed (Keynesian Thinking, p. 18). 
be much doubt on this matter, in view of Keynes' theory that the (typically) sudden break in prosperity is caused (typically) by a "sudden collapse in the marginal efficiency of capital"?

And what shall we say of Hansen's contention that when Keynes spoke of the duration of contractions as being "between, let us say, three and five years," he did not mean "about three to five years"? Hansen bases his argument on a part of this sentence from page 317 of the General Theory: "There are reasons, given firstly by the length of life of durable assets in relation to the normal rate of growth in a given epoch, and secondly by the carrying-costs of surplus stocks, why the duration of the downward movement should have an order of magnitude which is not fortuitous, which does not fluctuate between, say, one year this time and ten years next time, but which shows some regularity of habit between, let us say, three and five years." Now it is possible, to be sure, to interpret Hansen's quotation (I have italicized it) as meaning merely that the longest contraction is less than twice the duration of the shortest. ${ }^{10}$ But does this interpretation seem plausible? Did Keynes mean nothing by the "length of life of durable assets" or by the "carrying-costs of surplus stocks"? Hansen overlooks the fact that the sentence from which he quotes is part of a discussion of the factors that render "the slump so intractable." The discussion starts on page 316 . Keynes first expresses the view that a "considerable interval of time" must elapse before a recovery can get under way. The passage quoted by Hansen comes a little later, and should be read against the background of Keynes' obvious concern with the absolute duration of contractions. This, I think, narrows the uncertainty. If doubt remains concerning the meaning of the phrase "between, let us say, three and five years," it is whittled away by a similar phrase on page 318 , which definitely refers to the absolute period required for the absorption of stocks during a slump. ${ }^{11}$ And there is additional evidence of Keynes' meaning. He makes a recovery wait not only on the absorption of stocks, but also on the "shortage of capital through use, decay and obsolescence" causing "a sufficiently obvious scarcity to increase

${ }^{9}$ General Theory, p. 315. Gf. Keynesian Thinking, pp. 18-19.

10 On this interpretation (which seems to be Hansen's now) Keynes happens to be as wrong on the facts as in my interpretation (and Hansen's of earlier date). One can escape the discomfort once for all: if the passage quoted by Hansen is taken literally, I doubt if any facts could ever contradict it. There is, unhappily, a great abundance of ambiguous remarks throughout Keynes' chapter on business cycles. Under the circumstances, it is essential to work patiently, back and forth, over the text as a whole.

11 See also General Theory, pp. 331-332, where stocks are further discussed. 
the marginal efficiency" (p. 318). In view of the great durability of 'fixed' capital and the sharply reduced demands upon it during depression, can it be seriously argued that Keynes meant that this process could work itself out in a period much shorter than "say, three to five years"?

So much for the issue of the "straw man," which Hansen raised in connection with my account of the starting point of Keynes' theory. The theory itself I summarized as follows in the essay: " $\mathrm{His}$ [Keynes'] theory is that a collapse of investment brings prosperity to a close; that this in turn is caused by a collapse of confidence regarding the profitability of durable assets; and that the contraction which follows is bound to last, say, three to five years, since recovery is possible only after stocks have been worked off, and more important still, after the 'fixed' capital of business firms has been reduced sufficiently to restore its profitability." ${ }^{2}$ Hansen passes over this summary, but attempts to refute what I say of the collision between Keynes' theory and the facts of experience. I cited three such facts. Hansen asserts that "not one of them collides with Keynes' cycle theory," but he stops to examine only one-namely, that "the stock of durable goods in a growing country is virtually free from any trace of business cycles, increasing as a rule during contractions of business activity as well as during expansions." ${ }^{13}$ Hansen's argument, as best I can make out, is that

12 Keynesian Thinking, p. 18.

13 ibid., p. 19. Hansen disputes a portion of the statement just quoted. He states that the latter half is "quite all right," but "the first half is definitely in error." Here the difficulty rests on a purely verbal misunderstanding. The latter half of the statement, modifying as it does the first half, merely serves to explain the first half. If, therefore, the latter half is "quite all right," there is no real difficulty.

Although I meant to convey no more than what I have just stated (nothing else was required by the question under examination), it may be well to note that sta-1 tistics (expressed in a physical unit, for individual industries) suggest that the stock of industrial facilities not only increases, as a rule, during contractions as well as expansions of business cycles, but that the rate of increase itself is not systematically higher during a business cycle expansion than during adjacent contractions. How can this happen in view of the large fluctuations in the output of investment goods and of their close relation to business cycles? The reasons, put briefly, are as follows: (1) If the output of investment goods ascended linearly from the trough of a business cycle to a peak, then descended linearly to the date of the next business cycle trough; if, further, the output at successive troughs were identical, and likewise at successive peaks; if, finally, retirements were zero; then (barring qualitative distinctions) the stock of industrial facilities in place would increase at a consistently higher rate from midexpansion to midcontraction of business cycles than from midcontraction to midexpansion. (2) None of these assumptions is fulfilled in fact; and a little experimenting will indicate to what extent plausible departures from the model will introduce a haphazard element in the cyclical interval during which the rate of increase in the stock of industrial facilities is especially high or low. The most important randomizing factor in practice ( $I$ think) is the unevenness of the successive troughs and of 
this fact does not collide with Keynes' theory, since everyone-including Keynes-knows that net investment in fixed capital is usually positive even in depressions. ${ }^{14}$

If this is Hansen's argument, it is needlessly indirect. The question at issue is simply whether I am right or wrong in reporting Keynes' theory to be that "recovery is possible only . . . after the 'fixed' capital of business firms has been reduced sufficiently to restore its profitability." If I am right, Keynes' theory requires that net investment be, typically, negative in depressions. I maintained that this did not happen. Since Hansen agrees, the way to redeem Keynes is to demonstrate that I misrepresented his theory of recovery. Hansen has not tried to do this, and I do not believe that he would find the task especially easy. ${ }^{15}$

successive peaks in output; for this means, roughly speaking, that the level of output of investment goods is greater in some business cycles during expansions and in others during contractions. (3) The preceding statements are based on the tacit assumption that the output (in the sense of value added, in constant prices) of investment goods and the installation of completed facilities are coincident. Of course, there is apt to be here a substantial and highly variable lag, which serves powerfully to distort and diversify the timing of the accelerations and retardations in the stock of industrial facilities.

The whole subject of the cyclical behavior of the stock of industrial capital requires extensive statistical and theoretical analysis. What $I$ have said merely scratches the surface. But I have thought it advisable to indicate that Hansen's remarks concerning what is possible and what is not possible are very hasty.

14 An earlier statement of Hansen's may be of interest: "The depression is a period of cessation of growth. There need be no actual relapse in capital formation-the existing stock being fully maintained" (Full Recovery or Stagnation? p. 51). See also General Theory, p. 329 .

15 On this question, see ibid., especially pp. 105, 253, 317-318, and the Keynesian primer by Joan Robinson, Introduction to the Theory of Employment, p. 116. Cf. Tarshis, op.cit., pp. 384, 444, 448 . 